\title{
Effect of camphor on biochemical factors and gene expression of antioxidant enzymes, inflammatory and apoptotic factors against gentamicin-induced nephrotoxicity in rats
}

\author{
Ali Valibeik ${ }^{1,2,3}{ }^{\circledR}$, Negar Naderi $^{2,3}{ }^{\circledR}$, Abdolhakim Amini $^{\circledR}{ }^{\circledR}$, Niloufar Tavakoli Dastjerd $^{4}$, Sobhan Rahimi

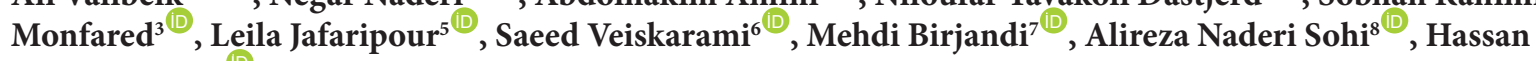 \\ Ahmadvand ${ }^{2,9 *(1)}$ \\ ${ }^{1}$ Student Research Committee, Lorestan University of Medical Sciences, Khorramabad, Iran \\ ${ }^{2}$ Hepatitis Research Center, Lorestan University of Medical Sciences, Khorramabad, Iran \\ ${ }^{3}$ Razi Herbal Medicines Research Center, Lorestan University of Medical Sciences, Khorramabad, Iran \\ ${ }^{4}$ Department of Medical Biotechnology, School of Allied Medical Sciences, Qazvin University of Medical Sciences, Qazvin, Iran \\ ${ }^{5}$ Department of Anatomy, Faculty of Medicine, Dezful University of Medical Sciences, Dezful, Iran \\ ${ }^{6}$ Lorestan Agricultural and Natural Resources Research and Education Center, Department of Animal Science, Khorramabad, Iran \\ ${ }^{7}$ Department of Biostatistics and Epidemiology, School of Health and Nutrition, Lorestan University of Medical Sciences, Khorramabad, \\ Iran \\ ${ }^{8}$ Stem Cell Technology Research Center, Tehran, Iran \\ ${ }^{9}$ Department of Clinical Biochemistry, School of Medicine, Lorestan University of Medical Sciences, Khorramabad, Iran
}

\section{A R T I C L E I N F O}

\section{Article Type:}

Original

\section{Article History:}

Received: 4 July 2020

Accepted: 22 September 2020

Published online: 9 October 2020

\section{Keywords:}

Gentamicin

Nephrotoxicity

Camphor

Biochemical factors

Antioxidant enzymes

Apoptotic factors

\begin{abstract}
A B S T R A C T
Introduction: Camphor is a natural antioxidant with anti-inflammatory and tissue repair properties. Nephrotoxicity is the most important side effect of gentamicin (GEM) administration. Therefore, investigating the effect of natural antioxidants can resolve this complication.

Objectives: We aimed to assay the effect of camphor on biochemical factors and gene expression of antioxidant enzymes (catalase [CAT], glutathione peroxidase [GPX]) and inflammatory markers (tumor necrosis factor-alpha [TNF- $\alpha$ ], nuclear factor kappa-B [NF- $\mathrm{BB}$ ], interleukine-6 [IL-6]), and apoptotic indices (BCL2-associated X protein [Bax], B-cell lymphoma 2 [Bcl-2], caspase-3)], against GEM-induced nephrotoxicity in rats.

Materials and Methods: Thirty adult male Wistar rats were allocated to five groups. Positive control and treatment groups were given GEM to induce nephrotoxicity. Animal treatment groups were treated with camphor in olive oil for 12 days. Renal biopsies, serum, extraction of renal tissue and urine of rats were taken after the twelfth day. Biopsies were examined for structural changes using a light microscope, moreover, apoptosis, desired biochemical and inflammatory factors, were investigated by suitable methods.

Results: Camphor had no effect on biochemical factors, including malondialdehyde (MDA), glutathione (GSH), nitric oxide (NO), urea, creatinine and urine protein. However, it reduced the gene expression of TNF- $\alpha$, NF- $\kappa$ B, IL- 6 , Bax, and caspase- 3 and increased the gene expression of GPX and CAT and Bcl-2. Moreover, camphor improved kidney histopathological changes in the camphor groups in comparison with the GEM group.

Conclusion: Camphor can be useful in the attenuation of GEM-induced nephrotoxicity based on expression levels of examined enzymes and factors and improving kidney histopathological changes.
\end{abstract}

Implication for health policy/practice/research/medical education:

It has been proposed that nephrotoxicity is the most important side effect of gentamicin use, in addition, camphor is a natural antioxidant. The present study aimed to evaluate the effect of camphor on biochemical factors and gene expression of antioxidant enzymes, inflammatory and apoptotic factors against gentamicin- induced nephrotoxicity in rats. Camphor can be useful in the attenuation of gentamicin-induced nephrotoxicity. However, more studies with more experimental groups and longer follow-up are necessary to confirm the results of this study.

Please cite this paper as: Valibeik A, Naderi N, Amini A, Tavakoli Dastjerd N, Rahimi Monfared S, Jafaripour L, Veiskarami S, Birjandi M, Naderi Sohi A, Ahmadvand H. Effect of camphor on biochemical factors and gene expression of antioxidant enzymes, inflammatory and apoptotic factors against gentamicin-induced nephrotoxicity in rats . J Renal Inj Prev. 2021; 10(3): e21. doi: 10.34172/jrip.2021.21. 


\section{Introduction}

The kidney is an essential organ of the body, which performs several vital functions, such as maintaining the body's homeostasis and organizing the extracellular environment (detoxification, excretion of toxins and drugs) (1). The kidneys constitute less than $0.5 \%$ of the body's weight and they receive $20 \%$ to $25 \%$ of cardiac output; thus, they are more prone to toxic damage (2). The kidneys have a significant role in excreting most drugs; since some drugs may have side effects on kidney function (3).

Aminoglycoside antibiotics including amikacin, neomycin, streptomycin, gentamicin (GEM) and tobramycin are frequently used to treat infections caused by gram-negative bacteria (4). The main complication induced by these antibiotics is nephrotoxicity (5). Nephrotoxicity is defined as the poisonous effect of substances on renal function (6). GEM, the most commonly used aminoglycoside, is associated with inducing the production of free radicals, decrease of antioxidant defenses and acute tubular necrosis which consequently motivates reducing glomerular filtration rate (GFR) and renal impairment (7).

Mechanisms of GEM-induced nephrotoxicity are associated with induction of transforming growth factorbeta 1 (TGF- $\beta$ ), endothelin-1, macrophages or monocyte infiltration into the renal cortex and medulla, oxidative stress and necrosis, and apoptosis (8). GEM is capable of increasing the number of reactive oxygen species (ROS) such as superoxide anions $\left(\mathrm{O}_{2}^{-}\right)$, hydroxyl radicals $(\cdot \mathrm{OH})$, and hydrogen peroxides $\left(\mathrm{H}_{2} \mathrm{O}_{2}\right)$. Moreover, GEM is able to raise reactive nitrogen species (RNS) in the renal cortex, which may lead to impaired kidney function and structure (9).

Numerous studies have been conducted to investigate the effect of antioxidants on GEM-induced nephrotoxicity (10). Camphor is a natural antioxidant and a ketone terpenoid with the chemical formula $\mathrm{C}_{10} \mathrm{H}_{16} \mathrm{O}$, that is found in the Cinnamomum camphora tree (11). Researches have shown that camphor effectively reduces pain, removes warts, treats hemorrhoids and osteoarthritis. Furthermore, it was suggested that it has anti-inflammatory, antioxidant and antimicrobial properties (12).

Rats are similar to humans in terms of anatomy, genetics and physiology; therefore, they are used as a preferred animal in many experimental studies (13). Although the pathogenesis of renal is complex, rats were employed in several studies as experimental animals to investigate kidney function and treatment in human (14).

\section{Objectives}

The primary object of the present study was to evaluate the effect of camphor on biochemical factors and gene expression of antioxidant enzymes (catalase [CAT], glutathione peroxidase $[\mathrm{GPX}]$ ), inflammatory (tumor necrosis factor-alpha [TNF- $\alpha$ ], nuclear factor kappa-B $[\mathrm{NF}-\kappa \mathrm{B}$ ], interleukine-6 [IL-6]) and apoptotic (Bax, Bcl-2, and caspase-3) factors against GEM-induced nephrotoxicity in rats. The secondary objectives were to (i) compare the serum urea and creatinine levels between the case and control groups, and (ii) compare levels of GPX, CAT, glutathione (GSH), malondialdehyde (MDA), and nitric oxide (NO) between the case and control groups.

\section{Materials and Methods \\ Study design}

In this experimental study, we investigated renal histology and function in the male adult Wistar albino rats, with GEM-induced nephrotoxicity.

\section{Animal models and housing conditions}

Thirty adult male Wistar rats (in the age range of 10 to 12 weeks and an average weight of $180 \pm 20 \mathrm{~g}$ ) were used in this study. The rats were housed under a 12-12 hour light-dark cycle, at a constant temperature/humidity (temperature of $23 \pm 2^{\circ} \mathrm{C}$ and air humidity of $50 \%$ to $55 \%$ ) and free access to water and food. Two weeks before the exposure, the animals were allowed to adapt to the new environment. The rats were randomly allocated to five groups (6 rats per group) and all animals were injected intra-peritoneally (IP).

\section{Preparation of camphor solution}

Camphor (C95\%, Sigma-Aldrich, Germany) was dissolved in olive oil. Treatment groups were treated with different dosages of camphor in olive oil (per kilogram of rat body weight) by oral gavage once a day in the morning time (Table 1).

Five groups of rats were treated as follows:

1. Negative control; $100 \mathrm{mg} / \mathrm{kg}$ of saline

2. Positive control; $100 \mathrm{mg} / \mathrm{kg}$ of saline and $100 \mathrm{mg} / \mathrm{kg}$ of GEM

3. Treated $1 ; 100 \mathrm{mg} / \mathrm{kg}$ of GEM and $50 \mathrm{mg} / \mathrm{kg}$ of camphor

4. Treated 2; $100 \mathrm{mg} / \mathrm{kg}$ of GEM and $150 \mathrm{mg} / \mathrm{kg}$ of camphor

5. Treated 3; $100 \mathrm{mg} / \mathrm{kg}$ of GEM and $300 \mathrm{mg} / \mathrm{kg}$ of camphor

\section{Histological studies}

The kidney was divided into two equal sections, then a section of the tissue was fixed in $10 \%$ buffered formaldehyde solution. Prepared tissues were cut at 4- $\mu \mathrm{m}$ thick using a microtome. Hematoxylin and eosin day was used to stain the tissue. The tissue sections were carefully examined for the presence of abnormalities using a light microscope with $\times 400$ magnification. Then, the method by Caramelo et al was applied to measure leukocyte infiltration, eosinophilic casts and tubular necrosis (Table 2) (15). 
Table 1. Properties of injection material and its dosages in the animal groups

\begin{tabular}{|c|c|c|c|}
\hline Groups & Injection material & Dosages (mg/kg) & Duration \\
\hline Negative control & Saline & 100 & For 12 days \\
\hline Positive control & Gentamicin + Saline (one hour after the injection of gentamicin) & $100+100$ & For 12 days \\
\hline Treated 1 & Gentamicin + (Camphor + Olive oil) (one hour after the injection of gentamicin) & $100+50$ & For 12 days \\
\hline Treated 2 & Gentamicin + (Camphor + Olive oil) (one hour after the injection of gentamicin) & $100+150$ & For 12 days \\
\hline Treated3 & Gentamicin + (Camphor + Olive oil) (one hour after the injection of gentamicin) & $100+300$ & For 12 days \\
\hline
\end{tabular}

Glomerular destruction and changes such as Bowman's space narrowing, glomerular adhesion into Bowman's capsule and glomerular collapse were distinguished by Çakir et al method (16). In this method, 0: no damage; 1: less than $25 \%$ of glomeruli was affected; $2: 25-50 \%$ of glomeruli was affected; 3: More than $50 \%$ of glomeruli was affected.

\section{Tissue extract preparation}

A slice of tissue sample was weighted and $10 \mathrm{~mL}$ of phosphate buffered saline (PBS) was added for each gram of tissue. The tissue was homogenized in ice-cold PBS buffer and used for biochemical tests.

\section{Assessment of biochemical factors}

All the rats were euthanized at the end of the twelfth day; for this purpose, the combination of ketamine-xylazine (KX) $(13 \mathrm{mg} / \mathrm{kg}$ and $87 \mathrm{mg} / \mathrm{kg}$, respectively) was used for anesthesia in rats. Animal blood samples were collected from their hearts using a $5 \mathrm{cc}$ syringe. The samples were incubated at room temperature for 15 minutes. The blood samples were centrifuged at $3000 \times \mathrm{g}$ for 10 minutes. Serum samples were collected in microtubes and stored at $-80^{\circ} \mathrm{C}$ before the examination. Serum and renal tissue activity of GPX and glutathione (GSH) was determined by the modified methods of Rotruck et al and Rahman et al, respectively $(17,18)$. The CAT enzyme activity of renal tissue was assessed by the modified method of Aebi (19). Thiobarbituric acid (TBA) assay was used to measure MDA (20). Serum NO levels were tested using a colorimetric Griess reaction and measurements of urea and creatinine of serum and urine were estimated using commercially available kits (Pars Azmoon kit, Tehran, Iran) (21). The turbidity method was used to estimate the

Table 2. Measuring leukocyte infiltration, eosinophilic casts and tubular necrosis by Caramelo et al method

\begin{tabular}{ll}
\hline Numerical score & Degree of tubular damage \\
\hline 0 & No damage \\
1 & Unicellular patchy isolated necrosis \\
2 & Tubular necrosis $<25 \%$ \\
3 & Tubular necrosis between $25 \%$ and $50 \%$ \\
4 & $>50 \%$ tubular necrosis \\
\hline
\end{tabular}

protein concentration of urine (22).

\section{Assessment of molecular factors (Real-Time PCR)}

RNA extraction was performed according to the instructions (23). Subsequently, the absorbance of the extraction solution was read at 260 and $280 \mathrm{~nm}$ on a NanoDrop. Then, the purification of RNA extraction products was checked using agarose gel electrophoresis and the presence of clear $28 \mathrm{~S}$ and 18S RNA bands was considered as high-quality RNA. The conversion of RNA into cDNA was performed using a commercially available kit (YTA, Yekta Tajhiz Azma, Iran) according to the manufacturer's instruction. Multiplex real-time polymerase chain reactions (PCR) were carried out. The reaction mixture contained 2 x SYBR Green qPCR Mix ( $1 \mathrm{X}), 0.2 \mu \mathrm{L}$ of primers for the desired gene (Table 3 ), $1 \mu \mathrm{L}$ of cDNA template and $8.2 \mu \mathrm{L}$ of RNAse free water (DEPC water). The ultimate volume of the reaction mixture $(20 \mu \mathrm{L})$ was examined for proliferation under these conditions: Initial denaturation step at $95^{\circ} \mathrm{C}$ for 3 minutes; then 40 cycles of denaturation for 5 seconds at $95^{\circ} \mathrm{C}$, and annealing for 30 seconds at $60^{\circ} \mathrm{C}$, followed by 5 minutes final extension step at $50-99^{\circ} \mathrm{C}$ in a Real-Time PCR System thermocycler. The products were loaded on $1 \%$ agarose gel in $1 \mathrm{X}$ TBE solution and PCR bands were observed with an UV transilluminator (Table 3).

\section{Ethical issues}

This study was confirmed by Local Ethics Committee of Lorestan University of Medical Sciences. As an experiment, the protocols were approved to be in accordance with the guidelines of Animal Ethics Committee of Lorestan University of Medical Sciences, Khorramabad, Iran (IR. LUMS.REC.1399.092). This study was extracted from the MSc thesis of Ali Valibeik at this University (Thesis \#1397-1-99-1528).

\section{Statistical analysis}

The analysis of all data was done by SPSS version 22.0 statistical software. One-way analysis of variance (ANOVA) and Tukey's post tests were used to compare the data. For non-parametric data, the Kruskal Wallis test and the Mann-Whitney $\mathrm{U}$ test together with the Bonferroni correction were used. The delta- delta $\mathrm{Ct}(\Delta \Delta \mathrm{Ct})$ method, also known as the $2^{-\Delta \Delta \mathrm{Ct}}$ method, was used to analyze gene 
Table 3. List of primers used in this study

\begin{tabular}{|c|c|c|c|c|}
\hline Primer & Oligonucleotide & Sequence $\left(5^{\prime}-3^{\prime}\right)$ & length (bp) & Reference \\
\hline CAT-F & \multirow{2}{*}{ CAT } & ATTGCCGTCCGATTCTCC & \multirow{2}{*}{105} & \multirow{2}{*}{ (33) } \\
\hline CAT-R & & CCAGTTACCATCTTCAGTGTAG & & \\
\hline GPX-F & \multirow{2}{*}{ GPX } & GGTGTTCCAGTGCGCAGAT & \multirow{2}{*}{68} & \multirow{2}{*}{ (34) } \\
\hline GPX-R & & AGGGCTTCTATATCGGGTTCGA & & \\
\hline Bax-F & \multirow{2}{*}{ Bax } & CGTGGTTGCCCTCTTCTACTTT & \multirow{2}{*}{73} & \multirow{2}{*}{ (35) } \\
\hline Box-R & & GATCAGCTCGGGCACTTTAGTG & & \\
\hline $\mathrm{Bcl} 2-\mathrm{R}$ & \multirow{2}{*}{$\mathrm{Bcl} 2$} & GATGACTTCTCTCGTCGCTA & \multirow{2}{*}{229} & \multirow{2}{*}{ (36) } \\
\hline $\mathrm{Bcl} 2-\mathrm{F}$ & & GTCATCCACAGAGAGCGATGTT & & \\
\hline TNF- $\alpha-F$ & \multirow{2}{*}{ TNF- $\alpha$} & CCAGGAGAAAGTCAGCCTCCT & \multirow{2}{*}{87} & \multirow{2}{*}{ (37) } \\
\hline TNF- $\alpha-R$ & & TCATACCAGGGCTTGAGCTC & & \\
\hline NF-kB-F & \multirow{2}{*}{ NF-kB } & AACACTGCCGAGCTCAAGAT & \multirow{2}{*}{345} & \multirow{2}{*}{ (38) } \\
\hline NF-KB-R & & CATCGGCTTGAGAAAAGGAG & & \\
\hline IL-6-F & \multirow{2}{*}{ IL-6 } & CGAAAGTCAACTCCATCTGCC & \multirow{2}{*}{74} & \multirow{2}{*}{ (39) } \\
\hline IL-6-R & & GGCAACTGGCTGGAAGTCTCT3 & & \\
\hline$\beta$-actin- $F$ & \multirow{2}{*}{$\beta$-actin } & TATCGGCAATGAGCGGTTCC3 & \multirow{2}{*}{150} & \multirow{2}{*}{$(40)$} \\
\hline$\beta$-actin-R & & AGCACTGTGTTGGCATAGAGG3 & & \\
\hline
\end{tabular}

expression. The probability of $P<0.05$ was considered statistically significant. The data were reported as means \pm SD in tables, and $\pm 95 \%$ confidence intervals on graphs.

Results

Biochemical parameters in the urine, serum, and extracted renal tissue

Table 4 presents the results of biochemical parameters in urine, serum and renal tissue. The CAT enzyme, GPX,
MDA and GSH activity levels in the renal tissue were significantly lower in the GEM group in comparison with the other groups $(P<0.001)$. However, there were no significant differences between the control group and the treatment groups. The GSH and GPX activity levels in the serum were significantly lower in the GEM group in comparison with the other groups $(\mathrm{P}<0.001)$, however, there were no significant differences between the control group and the treatment groups. The observed

Table 4. Biochemical factors and antioxidant enzymes in the urine, serum and extracted renal tissue

\begin{tabular}{|c|c|c|c|c|c|}
\hline Parameters & Control & Gentamicin & $\begin{array}{l}\text { Camphor } \\
\text { (50 mg/kg) }\end{array}$ & $\begin{array}{c}\text { Camphor } \\
(150 \mathrm{mg} / \mathrm{kg})\end{array}$ & $\begin{array}{c}\text { Camphor } \\
(300 \mathrm{mg} / \mathrm{kg})\end{array}$ \\
\hline $\begin{array}{l}\text { Renal tissue MDA ( } \mu \mathrm{mol} / \mathrm{mg} \\
\text { of proteins) }\end{array}$ & $45.7227 \pm 3.60246^{a, b}$ & $50.8081 \pm 5.84877^{b}$ & $45.5615 \pm 6.16445^{a, b}$ & $44.8032 \pm 7.31203^{a, b}$ & $37.7130 \pm 7.19601^{\mathrm{a}}$ \\
\hline $\begin{array}{l}\text { Serum MDA ( } \mu \mathrm{mol} / \mathrm{mg} \text { of } \\
\text { proteins) }\end{array}$ & $0.9861 \pm 0.41862^{\mathrm{a}}$ & $1.6030 \pm 0.22541^{b}$ & $1.4619 \pm 0.909^{a}$ & $1.4708 \pm 0.21151^{\mathrm{a}}$ & $1.4476 \pm 0.26916^{\mathrm{a}}$ \\
\hline $\begin{array}{l}\text { Renal tissue GSH ( } \mu \mathrm{mol} / \mathrm{mg} \\
\text { of proteins) }\end{array}$ & $3.0532 \pm 0.10245^{b}$ & $2.3257 \pm 0.22628^{a}$ & $2.4387 \pm 0.32439^{a}$ & $2.5337 \pm 0.24721^{\mathrm{a}, \mathrm{b}}$ & $2.3358 \pm 0.55557^{a}$ \\
\hline $\begin{array}{l}\text { Serum GSH ( } \mu \mathrm{mol} / \mathrm{mg} \text { of } \\
\text { proteins) }\end{array}$ & $0.2389 \pm 0.2218^{a}$ & $0.1873 \pm 0.2242^{\mathrm{a}}$ & $0.2713 \pm 0.3545^{b}$ & $0.2247 \pm 0.6848^{a}$ & $0.2422 \pm 0.2569^{a}$ \\
\hline $\begin{array}{l}\text { Renal tissue GPX ( } \mu \mathrm{mol} / \mathrm{mg} \\
\text { of proteins) }\end{array}$ & $254.4852 \pm 10.82917^{\mathrm{a}, \mathrm{b}}$ & $229.4864 \pm 23.3711^{a}$ & $298.5246 \pm 27.06573^{b}$ & $288.0397 \pm 35.56474^{b}$ & $303.3239 \pm 31.70671^{b}$ \\
\hline $\begin{array}{l}\text { Serum GPX ( } \mu \mathrm{mol} / \mathrm{mg} \text { of } \\
\text { proteins) }\end{array}$ & $41.6115 \pm 4.99075^{b}$ & $32.4124 \pm 4.31588^{\mathrm{a}}$ & $42.3743 \pm 1.36766^{b}$ & $42.8975 \pm 4.2373^{b}$ & $43.4986 \pm 5.28237^{b}$ \\
\hline $\begin{array}{l}\text { Renal tissue catalase (U/mg } \\
\text { of protein) }\end{array}$ & $5.9123 \pm 0.58203^{b}$ & $3.3883 \pm 0.37932^{\mathrm{a}}$ & $5.6323 \pm 0.58964^{b}$ & $5.8771 \pm 0.71047^{\mathrm{b}}$ & $5.5169 \pm 0.52477^{b}$ \\
\hline $\begin{array}{l}\text { Serum NO ( } \mu \mathrm{mol} / \mathrm{mg} \text { of } \\
\text { proteins) }\end{array}$ & $42.4190 \pm 2.5345^{a}$ & $46.4773 \pm 1.54674^{a}$ & $46.9857 \pm 2.44111^{b}$ & $48.3440 \pm 2.53129^{b}$ & $47.6357 \pm 3.12218^{b}$ \\
\hline Serum urea $(\mathrm{mmol} / \mathrm{L})$ & $35.3333 \pm 4.08248^{\mathrm{a}}$ & $90.3333 \pm 14.45914^{b}$ & $88 \pm 49.27^{b}$ & $68 \pm 25.069^{a, b}$ & $58.5 \pm 10.2127^{a, b}$ \\
\hline Urine urea (mmol/L) & $3700 \pm 645.98^{b}$ & $1716.6667 \pm 30605^{\mathrm{a}}$ & $1783.3333 \pm 645.47^{a}$ & $1700 \pm 673.79^{a}$ & $1837.5 \pm 301039^{a}$ \\
\hline Urine protein (mg/day) & $293.6250 \pm 110.062^{a}$ & $493.3125 \pm 61.077^{b}$ & $336.1250 \pm 80.071^{a, b}$ & $383 \pm 86.658^{a}$ & $312.3750 \pm 197.427^{a, b}$ \\
\hline Serum Creatinine (mg/dL) & $0.665 \pm 04278$ & $08533 \pm 0.19937$ & $0.9767 \pm 0.35303$ & $0.726 \pm 0.19501$ & $0.7283 \pm 0.8377$ \\
\hline Urine Creatinine (mg/dL) & $37.1667 \pm 2.2286$ & $24.5 \pm 4.83735$ & $21.25 \pm 7.80224$ & $29.9167 \pm 33.34$ & $17.5 \pm 3.58236$ \\
\hline
\end{tabular}

* Statistically significant differences between the groups are shown with different letters above the data (For example, a group with the letter a, is significantly different from groups with the letters $b, c$, and bc, however, is not significantly different from groups with the letters a, ab, and abc). 
concentrations of MDA, urea and $\mathrm{NO}$ in the serum were significantly higher in the GEM group in comparison with the other groups $(P<0.001)$ of rats. The creatinine concentration of urine and serum was not significantly different between the groups. The protein concentration of urine was significantly higher in the GEM group compared with the other groups $(P<0.001)$. Despite this, it did not differ significantly between the control group and the treatment groups. The concentration of urea in urine was significantly lower in the GEM group in comparison with the other groups $(P<0.001)$. However, it did not differ significantly between the control group and the treatment groups (Table 4).

\section{Histological studies}

Kidney tissue in the control group revealed a healthy histological structure of the renal tubular (Figure 1A). Kidney sections of the GEM group showed renal epithelial degeneration and tubular necrosis with leukocytes infiltration in the interstitial area and the epithelial cast of renal (Figure 1B). Kidney tissue of rats treated with camphor50 showed a typical histological structure with leukocytes infiltration in the interstitial area (Figure 1C). Kidney tissue from those treated with the camphor 150 group showed a typical histological structure with leukocytes infiltration in the interstitial area, epithelial degeneration and tubular necrosis (Figure 1D). Kidney sections treated with camphor300 showed similar findings to the camphor150 group (Figure 1E).

The rate of tubular necrosis in the GEM group had shown a significant increase compared to the control group. Camphor intake at three different doses was able to significantly reduce the rate of tubular necrosis compared to the GEM group, of course, camphor 50 had further reduced the rate of tubular necrosis compared to camphor 150 and group 300. However, the rate of tubular necrosis in none of the camphor-receiving groups was as low as in the control group (Table 5).

Leucocyte infiltration in the GEM group had shown a significant increase compared to the control group. Camphor intake at two doses of 50 and 150 was able to reduce the rate of lymphocyte infiltration compared to the GEM group. Of course, the mean lymphocyte infiltration in these two groups was different from the control group (Table 5).

The rate of eosinophilic cast in the GEM group had shown a significant increase compared to the control

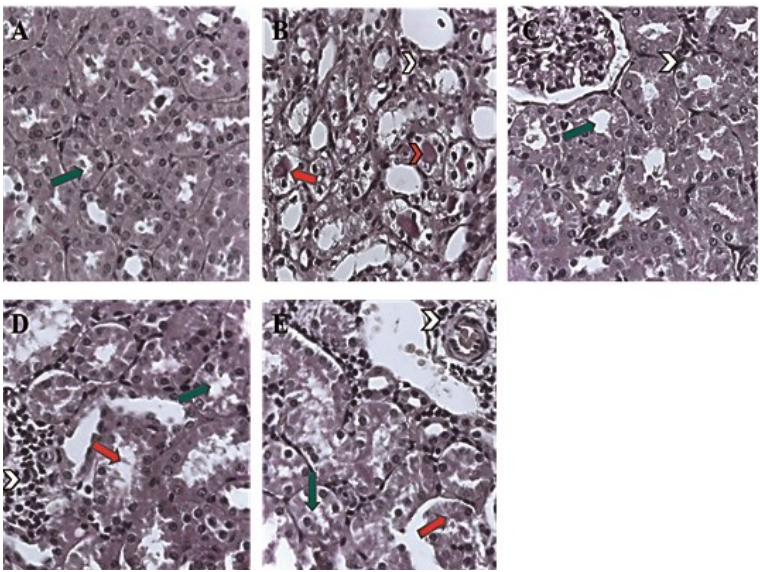

Figure 1. Photomicrographs (H\&E, 400x) of kidney tissue. A: Control group, B: Gentamicin group, C: Camfor50 group, D: Camfor150 group, E: Camfor300 group. The red arrow shows renal epithelial degeneration and tubular necrosis. The green arrow shows the typical histological structure of renal tubular. Red arrowhead shows the epithelial cast of renal. The whitehead arrow shows as leukocytes infiltration in the interstitial area.

group. Camphor intake at three different doses was able to reduce the eosinophilic cast rate in a promising manner compared to the GEM group. The comparison of the mean of these three groups with the control group shows that the amount of eosinophilic cast in these groups was reduced as much as the control group (Table 5).

The rate of glomerular damage in the GEM group had shown a significant increase compared to the control group. Camphor intake at three different doses was able to reduce the rate of glomerular degradation compared to the GEM group and the mean decrease in the three groups was slightly different from the mean of the control group (Table 5).

Gene expression of GPX, Catalase, TNF- $\alpha, N F-\kappa B, I L-6$, $B a x, B c l-2$, and caspase- 3 receptors

The gene expression of TNF- $\alpha$, NF- $\kappa B$, IL- 6 , Bax, and caspase- 3 factors in the renal tissue was significantly lower in the camphor group in comparison with the GEM group. However, the gene expression of GPX and CAT enzymes and Bcl-2 apoptotic factor was significantly higher in the camphor group in comparison with the GEM group (Figures 2 and 3).

Discussion

GEM is widely used to treat bacterial infections, however

Table 5. Tubular necrosis, leukocyte infiltration, eosinophilic casts and glomerular damage in control, gentamicin and camphor- treated groups

\begin{tabular}{|c|c|c|c|c|c|}
\hline & Control & Gentamicin & Camphor50 & Camphor150 & Camphor300 \\
\hline Tubular necrosis & $0.54 \pm 0.16^{\$}$ & $1.58 \pm 0.23^{\&}$ & $0.89 \pm 0.20^{8 \$}$ & $1.19 \pm 0.16^{\& \$}$ & $1.19 \pm 0.31^{\& \$}$ \\
\hline Leukocyte infiltration & $0.3 \pm 0.08^{\$}$ & $1.08 \pm 0.45^{\&}$ & $0.62 \pm 0.13^{\$}$ & $0.7 \pm 0.11^{\& \$}$ & $0.71 \pm 0.8^{\&}$ \\
\hline Eosinophilic casts & $0.49 \pm 0.31^{\$}$ & $1.25 \pm 0.54^{\&}$ & $0.51 \pm 0.08^{\$}$ & $0.46 \pm 0.05^{\$}$ & $058 \pm 0.08^{\$}$ \\
\hline Glomerular damage & $0.23 \pm 0.09^{\$}$ & $0.7 \pm 0.25^{\&}$ & $0.41 \pm 0.04^{\$}$ & $0.40 \pm 0.03^{\$}$ & $0.40 \pm 0.02^{\$}$ \\
\hline
\end{tabular}




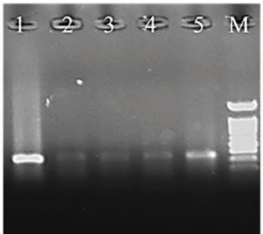

(a)
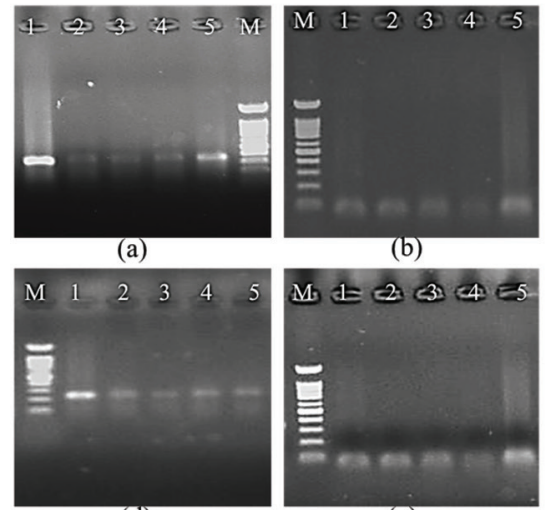

(d)

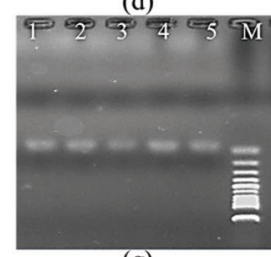

(g) (b)

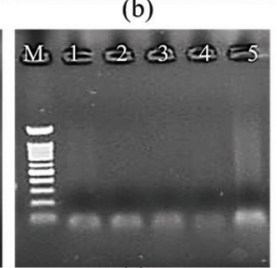

(e)

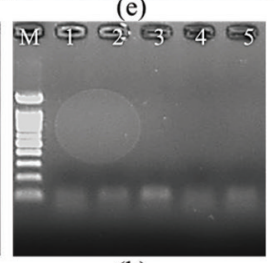

(h)

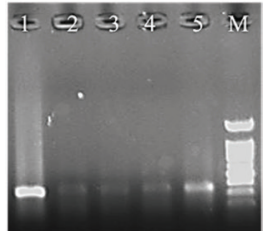

(c)

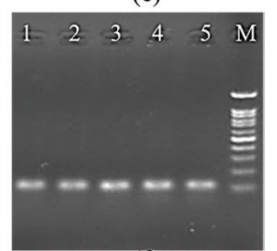

(f)

Figure 2. Analysis of PCR products by agarose gel electrophoresis. (a) NF-KB receptor, (b) TNF- $\alpha$ receptor, (c) IL-6 receptor, (d) Bcl-2 receptor, (e) Bax receptor, (f) caspase-3 receptor, (g) GPX receptor, (h) Catalase. Column M: Marker (100 bp), column 1: Control, column 2: Gentamycin, column 3: Camphor 50, column 4: Camphor 150, column 5: Camphor 300.

this antibiotic may cause severe renal impairment (24). Previous studies suggest that the interference of ROS with the renal is an impact of GEM. ROS, principally $\mathrm{O}_{2}$ - and $\cdot \mathrm{OH}$, induce cellular destruction and separation by different mechanisms, including repression of electron transport chain, destruction of respiration and ATP generation. Similar to humans and experimental animals, the increase of GEM in the renal leads to renal morphological transformations. Therefore, we chose this animal model to study biochemistry, histology and molecular assessment of GEM-induced nephrotoxicity (25). Various researchers have studied on the antioxidant properties of camphor as natural therapeutic agent for numerous human diseases (26). Camphor leaf is used to treat rheumatoid arthritis, muscular tension, intestinal disorder, rheumatic disease and pulmonary disorders (27). Hence, we did an experimental study to evaluate the effect of camphor on the change of renal function and histology in rats with GEM-induced nephrotoxicity.

Our study explained that the administration of GEM (100 $\mathrm{mg} / \mathrm{kg} / \mathrm{d}$ ) for 12 days, strongly caused nephrotoxicity in all treated rats. These results were supported by some previous studies $(28,29)$. GEM reduces the level of glomerular filtration that induces a rise in urea and creatinine of serum (9). Our study revealed that nephrotoxicity induced by GEM showed a marked decrease in the CAT, GPX, MDA and GSH activity levels of renal tissue and the GSH and GPX activity of serum, however, presented an increase in MDA, urea and $\mathrm{NO}$ activity in the serum, and did not show changes in creatinine concentration of

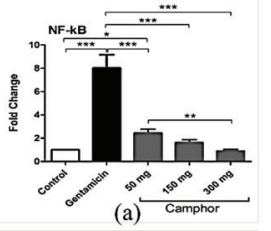

BCL2
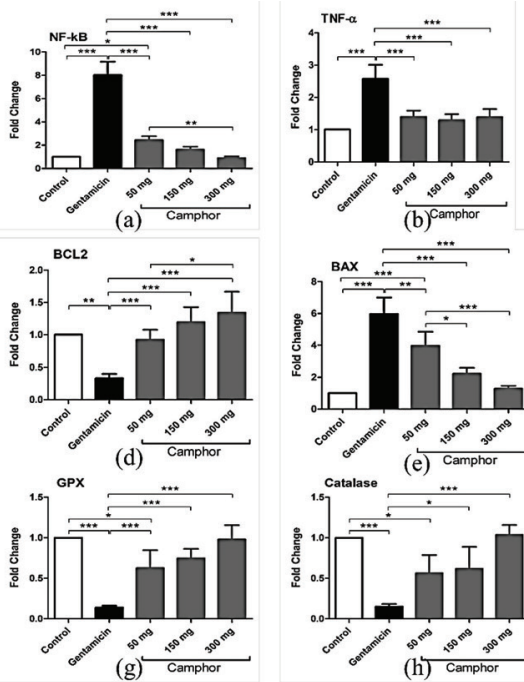

(b) Camphor
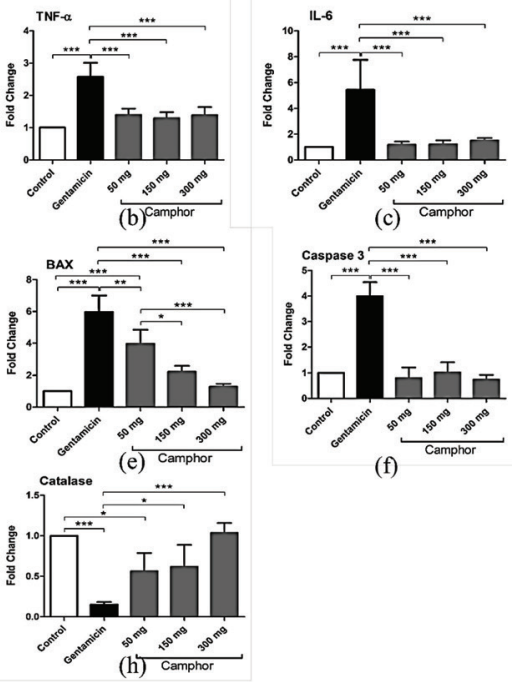

(f)
Figure 3. Effect of camphor on RNA expression of NF-kB, TNF- $\alpha$, IL6 , Bcl-2, Bax, caspase-3 GPX, and Catalase receptors in gentamicininduced nephropathy. Means \pm SE are shown. ${ }^{\star} P<0.01$, ${ }^{* *} P<0.001$, ${ }^{* * *} P<0.0001$, are significantly different from control using one-way ANOVA followed by Tukey-Kramer multiple comparisons post hoc test.

serum and urine. The insignificant levels of biochemical factors in the serum and renal tissue of camphor treated groups, as compared with the GEM group, indicated that the camphor may have no effect on biochemical reactions.

GEM does not generate morphological alterations in glomerulus. However, studies have revealed that high doses of GEM can generate moderate growth of glomeruli and circular transformation (30). Our study revealed that camphor 50 could improve the histological alterations induced by GEM.

Researches have shown that nephrotoxicity induced by GEM is related to high expression of p38-mitogen activated protein kinase (p38MAPK) and NF- $\kappa$ B pathways in kidney (31). Furthermore, oxidative stress that can be induced by GEM leads to the release of pro-inflammatory mediators such as TNF- $\alpha$ and interleukins such as IL1, IL-4, IL-6 (32). Treatment by GEM, up-regulates the expression of Bax protein and down-regulates the Bcl-2 expression (9). Our study showed a decrease in the gene expression of TNF- $\alpha$, NF- $\kappa$ B, IL- 6, Bax, and caspase- 3 factors and an increase in the gene expression of GPX and CAT enzymes and Bcl-2 apoptotic factor. Interpretation of decreased gene expression of TNF- $\alpha$, NF- $\kappa \mathrm{B}$, IL-6, and caspase- 3 factors is not supported by other studies.

\section{Conclusion}

This was the first study to explain that camphor could attenuate GEM-induced nephrotoxicity. As mentioned above, the results of this study demonstrated that camphor had no notable effect on biochemical factors like MDA, GSH, NO, urea, creatinine and urine protein. It considerably reduced the gene expression of inflammatory factors like NF- $\kappa \mathrm{B}$, TNF- $\alpha$ and IL- 6 and some apoptotic 
factors such as Bax and caspase-3. However, it significantly increased the gene expression of $\mathrm{Bcl}-2$ apoptotic factor and antioxidant enzymes such as GPX and CAT. In addition, improvement in histopathological changes was observed in the camphor-treated groups compared with the positive control group (GEM group).

In conclusion, camphor, due to its antioxidant properties, can be effective in improving kidney damage in some diseases and used as nephroprotective agent against kidney injury induced by nephrotoxins like GEM. However, more extensive studies with more experimental groups and longer follow-up are necessary to confirm the results of this study.

\section{Acknowledgements}

We thank the Hepatitis Research Center and the Razi Herbal Medicines Research Center for helping us with this study.

\section{Authors' contribution}

$\mathrm{AV}$ and HA were the principal investigators of the study. NN, AA, NTD, SRM and SV were the project collaborators. $\mathrm{MB}$ participated as a statistical consultant, ANS as a genetic consultant and LJP as a tissue collaborator. All authors participated in preparing the final draft of the manuscript, revised the manuscript and critically evaluated the intellectual contents. All authors read and approved the content of the manuscript and confirmed the accuracy or integrity of any part of the work.

\section{Conflicts of interest}

The authors declare that they have no conflict of interest.

Ethical considerations

Ethical issues (including plagiarism, data fabrication, double publication) have been completely observed by the authors.

\section{Funding/Support}

This experimental study was supported by Razi Herbal Medicines Research Center and Lorestan University of Medical Sciences, Khorramabad, Iran (Grant \#1397-1-991528).

\section{References}

1. Ferguson MA, Vaidya VS, Bonventre JV. Biomarkers of nephrotoxic acute kidney injury. Toxicology. 2008;245:18293. doi: 10.1016/j.tox.2007.12.024

2. Fattah H, Layton A, Vallon V. How Do Kidneys Adapt to a Deficit or Loss in Nephron Number? Physiology (Bethesda). 2019;34:189-97. doi: 10.1152/physiol.00052.2018

3. Pazhayattil GS, Shirali AC. Drug-induced impairment of renal function. Int J Nephrol Renovasc Dis.2014;7:457. doi: 10.2147/IJNRD.S39747

4. Krause KM, Serio AW, Kane TR, Connolly LE. Aminoglycosides: an overview. Cold Spring Harb Perspect
Med. 2016;6:a027029. doi: 10.1101/cshperspect.a027029

5. Wargo KA, Edwards JD. Aminoglycoside-induced nephrotoxicity. J Pharm Pract. 2014;27:573-7. doi: 10.1177/0897190014546836

6. Perazella MA. Renal vulnerability to drug toxicity. Clin J Am SocNephrol.2009;4:1275-83.doi:10.2215/CJN.02050309

7. Polat A, Parlakpinar H, Tasdemir S, Colak C, Vardi N, Ucar $\mathrm{M}$, et al. Protective role of aminoguanidine on gentamicininduced acute renal failure in rats. Acta Histochem. 2006;108:365-71. doi: 10.1016/j.acthis.2006.06.005

8. Bledsoe G, Crickman S, Mao J, Xia C-F, Murakami H, Chao L, et al. Kallikrein/kinin protects against gentamicininduced nephrotoxicity by inhibition of inflammation and apoptosis. Nephrol. Dial. Transplant. 2006;21:624-33. doi: 10.1093/ndt/gfi225

9. Randjelovic P, Veljkovic S, Stojiljkovic N, Sokolovic D, Ilic I. Gentamicin nephrotoxicity in animals: Current knowledge and future perspectives. EXCLI J. 2017;16:388. doi: 10.17179/excli2017-165

10. Pedraza-Chaverrí J, Maldonado PD, Medina-Campos ON, Olivares-Corichi IM, de los Ángeles Granados-Silvestre Ma, Hernández-Pando R, et al. Garlic ameliorates gentamicin nephrotoxicity: relation to antioxidant enzymes. Free Radic Biol Med. 2000;29:602-11. doi: 10.1016/S08915849(00)00354-3

11. Green BG. Sensory characteristics of camphor. J Invest Dermatol. 1990;94:662-6. doi: 10.1111/1523-1747. ep 12876242

12. Coté H, Boucher M-A, Pichette A, Legault J. Antiinflammatory, antioxidant, antibiotic, and cytotoxic activities of Tanacetum vulgare L. essential oil and its constituents. Medicines (Basel). 2017;4:34. doi: 10.3390/ medicines 4020034

13. Bryda EC. The Mighty Mouse: the impact of rodents on advances in biomedical research. Mo Med. 2013;110:207.

14. Mullins LJ, Conway BR, Menzies RI, Denby L, Mullins JJ. Renal disease pathophysiology and treatment: contributions from the rat. Dis Model Mech. 2016;9:141933. doi: $10.1242 / \mathrm{dmm} .027276$.

15. Caramelo C, Espinosa G, Manzarbeitia F, Cernadas M, Tejerizo GP, Tan D, et al. Role of endothelium-related mechanisms in the pathophysiology of renal ischemia/ reperfusion in normal rabbits. Circ Res. 1996;79:1031-8. doi: 10.1161/01.res.79.5.1031.

16. Çakir T, Polat C, Baştürk A, Gül M, Aslaner A, Durgut $\mathrm{H}$, et al. The effect of alpha lipoic acid on rat kidneys in methotrexate induced oxidative injury. Eur Rev Med Pharmacol Sci. 2015;19:2132-9.

17. Rotruck JT, Pope AL, Ganther HE, Swanson A, Hafeman DG, Hoekstra W. Selenium: biochemical role as a component of glutathione peroxidase. Science. 1973;179:588-90. doi: 10.1126/science. 179.4073 .588

18. Rahman I, Kode A, Biswas SK. Assay for quantitative determination of glutathione and glutathione disulfide levels using enzymatic recycling method. Nat Protoc. 2006;1:3159. doi: 10.1038/nprot.2006.378

19. Aebi H. Catalase in vitro in method of enzymology. Meth. Enzymol. 1984:121-6. doi: 10.1016/s0076-6879(84)05016-3

20. Uchiyama M, Mihara M. Determination of malonaldehyde precursorin tissues by thiobarbituric acid test. Anal Biochem. 
1978;86:271-8. doi:10.1016/0003-2697(78)90342-1

21. Coneski PN, Schoenfisch MH. Nitric oxide release: part III. Measurement and reporting. Chem Soc Rev. 2012;41:37538. doi: $10.1039 / \mathrm{c} 2 \mathrm{cs} 15271 \mathrm{a}$

22. Bollin Jr E, Schifreen RS. Turbidimetric method for measuring protein in urine and cerebrospinal fluid. Google Patents; 1984, US Patent 4,485,176.

23. Rio DC, Ares M, Hannon GJ, Nilsen TW. Purification of RNA using TRIzol (TRI reagent). Cold Spring Harb Protoc. 2010;2010:pdb.prot5439. doi: 10.1101/pdb.prot5439

24. Nafiu AO, Akomolafe RO, Alabi QK, Idowu CO, Odujoko OO. Effect of fatty acids from ethanol extract of Moringa oleifera seeds on kidney function impairment and oxidative stress induced by gentamicin in rats. Biomed. Pharmacother. 2019;117:109154. doi: 10.1016/j.biopha.2019.109154

25. Martínez-Salgado C, Eleno N, Morales AI, PérezBarriocanal F, Arévalo M, López-Novoa JM. Gentamicin treatment induces simultaneous mesangial proliferation and apoptosis in rats. Kidney Int. 2004;65:2161-71. doi: 10.1111/j.1523-1755.2004.00642.x

26. Chaturvedi T, Kumar A, Kumar A, Verma RS, Padalia RC, Sundaresan V, et al. Chemical composition, genetic diversity, antibacterial, antifungal and antioxidant activities of camphor-basil (Ocimum kilimandscharicum Guerke). Ind Crops Prod. 2018;118:246-58. doi: 10.1016/j. indcrop.2018.03.050

27. Li Y-R, Fu C-S, Yang W-J, Wang X-L, Feng D, Wang X-N, et al. Investigation of constituents from Cinnamomum camphora (L.) J. Presl and evaluation of their antiinflammatory properties in lipopolysaccharide-stimulated RAW 264.7 macrophages. J Ethnopharmacol. 2018;221:3747. doi: 10.1016/j.jep.2018.04.017

28. Al-Azzam S, Abdul-Razzak K, Jaradat M. The nephroprotective effects of pioglitazone and glibenclamide against gentamicin-induced nephrotoxicity in rats: a comparative study. J Chemother. 2010;22:88-91. doi: 10.1179/joc.2010.22.2.88

29. Medić B, Stojanović M, Rovčanin B, Kekić D, Škodrić SR, Jovanović GB, et al. Pioglitazone attenuates kidney injury in an experimental model of gentamicin-induced nephrotoxicity in rats. Sci Rep. 2019;9:1-10. doi: 10.1038/ s41598-019-49835-1

30. Stojiljkovic N, Mihailovic D, Veljkovic S, Stoiljkovic M, Jovanovic I. Glomerular basement membrane alterations induced by gentamicin administration in rats. Exp. Toxicol. Pathol. 2008;60:69-75. doi: 10.1016/j.etp.2008.02.007

31. Jaikumkao K, Pongchaidecha A, Thongnak L-o, Wanchai $\mathrm{K}$, Arjinajarn P, Chatsudthipong V, et al. Amelioration of renal inflammation, endoplasmic reticulum stress and apoptosis underlies the protective effect of low dosage of atorvastatin in gentamicin-induced nephrotoxicity. PLoS One. 2016;11:e0164528. doi: 10.1371/journal.pone.0164528

32. Falayi OO, Ogunpolu BS, Oyagbemi AA, Omobowale TO, Yakubu MA, Adedapo AA. Influence of oxidative stress and $\mathrm{NF}-\kappa \beta / \mathrm{CRP} / \mathrm{Bcl}-2$ signaling on gentamicin induced renal toxicology and the ameliorative effect of chloroform extract of Abrus precatorius in male Wistar rats. FASEB J. 2020; 34:1-1. doi:10.1096/fasebj.2020.34.s1.01780

33. Guimaraes-Ferreira L, Pinheiro CHJ, Gerlinger-Romero F, Vitzel KF, Nachbar RT, Curi R, et al. Short-term creatine supplementation decreases reactive oxygen species content with no changes in expression and activity of antioxidant enzymes in skeletal muscle. Eur J Appl Physiol. 2012;112:3905-11. doi: 10.1007/s00421-012-2378-9

34. Al-Rejaie SS, Aleisa AM, Sayed-Ahmed MM, Al-Shabanah OA, Abuohashish HM, Ahmed MM, et al. Protective effect of rutin on the antioxidant genes expression in hypercholestrolemic male Westar rat. BMC Complement Altern Med. 2013;13:136. doi: 10.1186/1472-6882-13-136

35. Kim H, Morimoto Y, Ogami A, Nagatomo H, Hirohashi M, Oyabu T, et al. Differential expression of EC-SOD, Mn-SOD and CuZn-SOD in rat lung exposed to crystalline silica. J Occup health. 2007;49:242-8. doi: 10.1539/joh.49.242

36. Han J, Zhang S, Liu X, Xiao C. Fabrication of capsaicin emulsions: improving the stability of the system and relieving the irritation to the gastrointestinal tract of rats. J Sci Food Agric. 2020;100:129-38. doi: 10.1002/jsfa.10002.

37. Ding Y, Young CN, Li J, Luan X, McAllister II JP, Clark JD, et al. Reduced inflammatory mediator expression by prereperfusion infusion into ischemic territory in rats: a realtime polymerase chain reaction analysis. Neurosci Lett. 2003;353:173-6. doi: 10.1016/j.neulet.2003.09.055

38. Hao J, Ren L, Zhang L, Kong D, Hao L. Aldosterone-induced inflammatory response of mesangial cells via angiotension II receptors. J Renin Angiotensin Aldosterone Syst. 2015; 16:739-48. doi: 10.1177/1470320313519486

39. Chung M-K, Asgar J, Lee J, Shim M, Dumler C, Ro J. The role of TRPM2 in hydrogen peroxide-induced expression of inflammatory cytokine and chemokine in rat trigeminal ganglia. Neuroscience. 2015;297:160-9. doi: 10.1016/j. neuroscience.2015.03.067

40. Zhong X, Deng J, He P, You N, Wang Q, Song B, et al. Reverse mode of the sodium/calcium exchanger subtype 3 in interstitial cells of Cajal from rat bladder. Urology. 2013;82(1):254.e7-e12. doi: 10.1016/j.urology.2013.02.049

Copyright ( 92021 The Author(s); Published by Nickan Research Institute. This is an open-access article distributed under the terms of the Creative Commons Attribution License (http://creativecommons.org/licenses/by/4.0), which permits unrestricted use, distribution, and reproduction in any medium, provided the original work is properly cited. 